\title{
Proximate composition, phytochemical analysis and antioxidant capacity of Aloe vera, Cannabis sativa and Mentha longifolia
}

Zeenat Waris ${ }^{1}$, Yousaf Iqbal ${ }^{1}$, Arshad Hussain ${ }^{2}$, Shafqatullah ${ }^{2}$, Asad Ali $\mathrm{Khan}^{3}$, Akhtar Ali ${ }^{3 *}$ and Mohammad Wasiullah Khan ${ }^{4}$

1. Institute of Chemical Sciences, The University of Peshawar-Pakistan

2. PCSIR Laboratories Complex Peshawar-Pakistan

3. Department of Agronomy, The University of Agriculture Peshawar-Pakistan

4. Department of Horticulture, The University of Agriculture Peshawar-Pakistan

Corresponding author's email: akhtarali@aup.edu.pk

Citation

Zeenat Waris, Yousaf Iqbal, Arshad Hussain, Shafqatullah, Asad Ali Khan, Akhtar Ali and Mohammad Wasiullah Khan. Proximate composition, phytochemical analysis and antioxidant capacity of Aloe vera, Cannabis sativa and Mentha longifolia. Pure and Applied Biology. Vol. 7, Issue 3, pp1122-1130. http://dx.doi.org/10.19045/bspab.2018.700131

Received: 13/04/2018

Revised: 02/08/2018

Accepted: 03/08/2018

Online First: 05/08/2018

\section{Abstract}

Plants, miracle of nature, are able to synthesize hundreds of chemical compounds for various metabolic functions. Numerous phytochemicals (secondary metabolites) with potential biological activity have been identified in most of the plant species. In order to determine the proximate composition, phytochemical analysis and antioxidant capacity of three well known selected plants species, a study was carried out during June 2016 in Khyber Pakhtunkhwa Peshawar. The plants under study were Aloe vera Linn (leaves), Cannabis sativa Linn (whole plant) and Mentha longifolia Linn (whole plant) in PCSIR Labs Complex Peshawar. The results from proximate analysis indicated that the plants contained crude protein in the range 0.447 to $0.953 \%$, crude fiber ranged from 12.33 to $28.47 \%$ and crude fat in the range of 5.87 to $14.86 \%$. Furthermore, analysis showed the presences of important phytochemicals such as tannins, flavonoids, alkaloids, glycosides and saponins in the investigated species. Antioxidant activity of the selected plants by DPPH (2,2-diphenyl-1-picrylhydrazyl radical) scavenging assay and using ascorbic acid as a standard indicated that Cannabis sativa and Aloe vera has the strongest and nearly the same activity with $\mathrm{IC}_{50} 353 \mu \mathrm{g} / \mathrm{ml}$. These plants can be used as herbal products.

Keywords: Antioxidants; Chemical analysis; Phytochemicals

\section{Introduction}

Plants are miracle of nature and owned the most valuable medicinal properties. Medicinal plants are considered to be the backbone of traditional medicine. About $80 \%$ of the world's community lives in less developed countries and rely more on plants for their medical purposes. According to WHO, about $80 \%$ people in these countries regularly use these traditional medicines for their primary health requirements [1]. About 6,000 species of higher plants have been 
reported in Pakistan. Out of which $12 \%$ species are known for its medicinal value [2]. Literature revealed that these plants contain active chemical constituents like phytochemicals, minerals and vitamins [3]. Phytochemical are chemicals produced by plants through primary or secondary metabolism. Medicinal plants having these bioactive chemicals with high proportion of antioxidants are considered fundamental in the prevention of a variety of degenerative diseases and have potential benefits to the people [4]. Antioxidants are chemicals that prevent oxidation and thereby remove potentially damaging oxidizing agents from a living cell. Free radicals like reactive oxygen and reactive nitrogen species (RONS) are molecules or molecular fragments having an unpaired electron. RONS is a combined term and consists of two classes, reactive oxygen species (ROS) and reactive nitrogen species (RNS). These free radicals are considerably unstable and extremely reactive due to the presence of unpaired electrons. During the sequence of chemical reactions that produce energy for our cells in mitochondrial respiration, ROS and RNS are naturally produced as byproducts of this essential process [5]. Antioxidants protect body against the harmful effects of uncontrolled reactive oxygen species and counteract their side effects. A number of radical scavenging antioxidants are common in food sources like fruits, vegetables and tea, etc [6].

Aloe vera Linn (A. vera). contains more than 75 nutrients and 200 active compounds, including minerals, enzymes, vitamins, sugars, amino acids, saponins, anthraquinone lignin and salicylic acid [7]. In conventional medicine, its gel has been applied in the cure of skin complaints like wounds, burns, skin irritations and pimples. It has also been used in constipation, headache, ulcers, arthritis, asthma, jaundice, diabetes and coughs. The bioactive compounds present in $A$. vera possess analgesic, antiseptic, antibacterial, anti-diabetic, antioxidant, anti-inflammatory and anticancer properties [8, 9]. Aloin, mixture of glycosides, is the active ingredient of various drugs. Despite this, the cosmetic and medicinal industries regularly use $A$. vera for soothing, moisturizing and healing ability [10]. It has also been used in the manufacture of lotion, soaps, shampoos, powders, creams, facial cleansers, capsules and so many other products both for external and internal uses [11]. Plant helps in nervous system functioning, enzymes activation, regulation of body liquids and so on due to the presence of calcium, magnesium, zinc, manganese, chromium, sodium, potassium etc $[12,13]$.

Cannabis sativa Linn ( $C$. sativa) contains about 104 cannabinoids which are the most attractive constituents [14]. Its seed contains carbohydrates about $30 \%$, protein $25 \%$, insoluble fiber $15 \%$, potassium, phosphorus, sulphur, calcium, magnesium, iron, zinc along with vitamin B6, B1, B2, B3, D, E and C [15]. Extracts and tinctures obtained from C. sativa were used for numerous different complaints including pain, whooping cough, asthma, and as a sedative/hypnotic agent [16]. Extracts are also used to treat glaucoma, AIDS, eye problems, muscle spasticity, insomnia, convulsion, depression, hypertension and treatment of pain $[17,18]$. These cannabinoids are also proved to delay and prevent the growth of cancer cells [19]. Mentha longifolia Linn (M. longifolia) is used for the treatment of bronchitis, flatulence, liver complaints and ulcerative colitis due to its anti-inflammatory, stimulant, emmenagogue, carminative, antioxidant, antispasmodic, cytotoxic and anticatharral activities [20]. Its extracts are used for relieving cold, cough, headache, stomach cramps and indigestion [21]. It is good for the treatment of whooping cough, muscle spasm, asthma, skin ulcer and hemorrhoids. It is also used for the treatment 
of rheumatism and other painful infections [22].

\section{Materials and methods}

\section{Collection and identification of plant materials}

Fresh plant samples of A. vera Linn, C. sativa Linn and M. longifolia Linn were collected from the botanical garden of Pakistan council of scientific and industrial research laboratories complex (PCSIR) Peshawar and Palosi fields Peshawar. The plants were identified by Dr. Arshad Hussain (Senior Scientific Officer) PCSIR Labs Complex Peshawar. All the chemicals and equipments were provided by PCSIR Labs Complex Peshawar. The collected leaves (A. vera) and whole plant (C. sativa and $M$. longifolia) were first cleaned with running tap water and then with distilled water to remove dust and sand etc. These plants materials were air dried in shade for few days. The dried plant materials were crushed to fine powder in an electric blender, stored in polythene bags and were tagged. Then different extracts were made ready by using the standard methods [23].

Preparation of extract for proximate and phytochemical analysis

Plant material (5g) was dissolved in about 90 $\mathrm{ml}$ water and boiled for 15 minutes, cooled and was filtered by using Whatmann filter paper No. 42 and then $100 \mathrm{ml}$ volume was made in volumetric flask. This solution was used in phytochemical and proximate analysis procedures.

Preparation of extracts for antioxidant analysis

Plant sample of $5 \mathrm{~g}$ was dissolved in $100 \mathrm{ml}$ of acetone and kept on orbital shaker for one week. The extract were then concentrated on rotary evaporator at $40^{\circ} \mathrm{C}$ and stored for antioxidant assay determination.

\section{Proximate analysis}

Proximate analysis of the selected medicinal plants involved determination of moisture, ash, crude protein, crude fat, crude fiber, $\mathrm{pH}$, total acidity and total soluble solids. All these were found out by manual methods [23].

Phytochemical screening

Phytochemical screening for the presence of tannins, alkaloids, flavonoids, triterpenoids, saponins, glycosides and steroids was carried out qualitatively [24, 25].

\section{Alkaloids}

The presence of alkaloids was confirmed by the following tests.

Mayer's test

To aqueous extract in a test tube, small amount of Mayer's reagent was carefully added along the walls. Development of creamy precipitate indicated alkaloids in the sample.

Wagner's test

To each aqueous extract in test tube, about 1 $\mathrm{ml}$ of Wagner's reagent 1 was added drop wise. Formation of reddish brown ppt was an indication for the presence of alkaloids.

\section{Flavonoids}

The presence of flavonoids was confirmed by the following tests

Ammonia solution test

To the aqueous extract, little amount of $1 \%$ ammonia solution was added to the test tube. Existence of flavonoids was detected by the formation of yellow colour.

\section{Ferric chloride test}

To the extract of plant material in a test tube, a number of drops of $\mathrm{FeCl}_{3}$ solution were added, formation of green/black coloration was an indication for flavonoids.

\section{Tannins}

In a test tube, about $0.5 \mathrm{~g}$ crushed plant material was heated to boiling with $20 \mathrm{ml}$ of distilled water, followed by the addition of $0.1 \% \mathrm{FeCl}_{3}$, formation of blue or black color indicated tannins in the sample.

\section{Saponins}

Powdered sample of $2 \mathrm{~g}$ was boiled with 20 $\mathrm{ml}$ of distilled water for some time. Extract of $5 \mathrm{ml}$ was shaken vigorously with $10 \mathrm{ml}$ distilled water for 10 minutes. Persistence of 
froth on heating was an indication for the presence of saponins.

\section{Triterpenoids}

In $2 \mathrm{ml}$ chloroform $\left(\mathrm{CHCl}_{3}\right)$, about $5 \mathrm{mg}$ of the powdered sample was added, followed by the addition of $1 \mathrm{ml}$ acetic anhydride very carefully along the walls and $1 \mathrm{ml}$ sulphuric acid $\left(\mathrm{H}_{2} \mathrm{SO}_{4}\right)$. Formation of reddish violet color showed the presence of triterpenoid.

\section{Steroids}

Powdered sample $(1 \mathrm{gm})$ was added in $10 \mathrm{ml}$ chloroform and concentrated $\mathrm{H}_{2} \mathrm{SO}_{4}(1 \mathrm{ml})$ was added into the tube using side walls. Two layers were formed, upper layer became red and the lower layer of $\mathrm{H}_{2} \mathrm{SO}_{4}$ displayed yellow color with green fluorescence and indicated steroids.

\section{Glycosides}

Extract of plant samples was reacted with hydrochloric acid followed by neutralization with sodium hydroxide. Then some amount of Fehling A and Fehling B was added. Formation of red precipitates indicated glycosides.

\section{Antioxidant assay (DPPH scavenging} activity)

Stable DPPH (2,2-diphenyl-1picrylhydrazyl radical) radical was used as a reagent in this method which shows absorbance at $517 \mathrm{~nm}$ on UV visible spectrophotometer and the presence of antioxidant in test solution decreased its concentration with time. This results in the disappearance of absorption and colour change from purple to yellow. In 95\% methanol, $0.004 \%$ w/v DPPH solution was made for present research work. Ascorbic acid (vitamin C) was used as reference standard [27].

DPPH scavenging (\%) was calculated by following formula:

\section{Results and discussion}

The results (Table 1) of proximate analysis of $A$. vera, $M$. longifolia and $C$. sativa revealed that moisture content was found highest (6.8\%) in A. vera, $5.5 \%$ C. sativa and $5.2 \%$ in M. longifolia. Water is the major part of the body cells. It helps to cushion and lubricate the brain and the joints and also helps to transport nutrients and waste. Water helps in regulation of body temperature and blood pressure.

Ash content was analyzed in the range of 3.17 to $4.33 \%$. Maximum ash was found in $C$. sativa and minimum in $M$. longifolia. Ash is actually the residue left after all the moisture and organic matter has been removed at high temperature. High ash content of these plants is actually a measure of the mineral richness [26]. Maximum crude fat was studied in A. vera and minimum in $M$. longifolia. In living organisms, fat are the usual stored absorbance of the control

forms of energy. They are the main structural element of phospholipids and sterol [28].

Crude fiber contents showed the maximum value for $M$. longofolia $28.47 \%$ and minimum $12.33 \%$ for $A$. vera. Crude fiber enhances digestibility and is considered excellent in the cure of gastrointestinal disorders, diabetes, obesity and cancer [29]. Similarly crude protein percentage of medicinal plants (Table 1) were found highest $(0.95 \%)$ for $A$. vera, followed by $C$. sativa $(0.76 \%)$ and lowest $(0.45 \%)$ in $M$. longifolia. Total sugar contents and total acidity (Table 1) in selected plants were in the range of $07.60 \%$ to $1.90 \%$ and 03.04 to 02.02 respectively. Total soluble solids were analyzed in the range of 1.57 to 0.01 . A slight acidic $\mathrm{pH}$ of $10 \%$ solution of all plants were obsereved in the range of 4.83 and 3.90 .

A. vera was investigated for different parameters including proximate analysis and reported $7.3 \%$ moisture, $8.72 \%$ ash, $5.4 \%$ 
crude fat $8.4 \%$ crude fiber and $16.2 \%$ crude protein. The reported data was in accordance with the present research findings [30]. The proximate analysis of the $C$. sativa plant parts separately and reported $6.87 \%$ moisture, $11.18 \%$ ash, $23.78 \%$ crude proteins and $18.95 \%$ crude fiber in the leaf. Likewise in stem, $17.20 \%$ crude protein, $23.13 \%$ crude fiber, $6.78 \%$ ash and $5.16 \%$ moisture was determined. While in seeds of $C$. sativa $20.19 \%$ crude protein, $25.36 \%$ crude fiber, $5.91 \%$ moisture and $7.20 \%$ ash was measured [31].

Table 1. Proximate analysis of Aloe vera, Cannabis sativa and Mentha longifolia

\begin{tabular}{|c|l|c|c|c|}
\hline S. No. & \multicolumn{1}{|c|}{ Constituents } & $\begin{array}{c}A . \text { vera } \\
\text { (leaves) }\end{array}$ & $\begin{array}{c}\text { C. sativa } \\
\text { (whole plant) }\end{array}$ & $\begin{array}{c}\text { M. longifolia } \\
\text { (whole plant) }\end{array}$ \\
\hline 1 & Moisture (\%) & $6.8 \pm 0.43^{*}$ & $5.5 \pm 0.49$ & $5.2 \pm 0.82$ \\
\hline 2 & Ash (\%) & $03.66 \pm 0.50$ & $04.33 \pm 0.58$ & $03.17 \pm 0.29$ \\
\hline 3 & Crude fat (\%) & $14.86 \pm 1.02$ & $11.17 \pm 1.14$ & $05.87 \pm 0.35$ \\
\hline 4 & Crude fiber (\%) & $12.33 \pm 1.15$ & $16.87 \pm 0.35$ & $28.47 \pm 0.81$ \\
\hline 5 & Crude Protein (\%) & $0.95 \pm 0.31$ & $0.76 \pm 0.35$ & $0.44 \pm 0.38$ \\
\hline 6 & Total sugar & $01.90 \pm 0.20$ & $03.40 \pm 0.17$ & $07.60 \pm 0.35$ \\
\hline 7 & Total acidity(10\%sol) & $2.02 \pm 0.002$ & $2.3 \pm 0.002$ & $03.04 \pm 0.01$ \\
\hline 8 & Total S S(10\% sol) & $0.01 \pm 0.004$ & $01.57 \pm 0.31$ & $0.40 \pm 0.03$ \\
\hline 9 & PH(10\% sol) & $04.7 \pm 0.05$ & $04.83 \pm 0.35$ & $03.90 \pm 0.26$ \\
\hline
\end{tabular}

*Mean \pm S.D $(\mathrm{n}=3)$

\section{Phytochemical analysis}

Phytochemical analysis of the selected plant samples were carried out using suitable procedure [24, 25]. Plants were examined (Table 2) for tannins, saponins, alkaloids, flavonoids, triterpenoid, steroids and glycosides.

Alkaloids, flavonoids, saponins, steroids, triterpenoids were detected in all the three plants while tannins were absent in $M$. longifolia. Glycosides were detected only in C. sativa and absent in rest of the plants. Thus maximum number of phytochemicals (secondary metabolites) was present in $C$. sativa. Different phytochemicals have been revealed to perform a large variety of actions. Like alkaloids protect against chronic diseases [34]. Alkaloids are beneficial to plants and serve as repellant to parasites and predators and show antimicrobial and pain
The proximate analysis of four medicinal plants [32] including $M$. longifolia and reported the highest crude protein value of $7.49 \%$ and $2.34 \%$ of crude fat in M. longifolia [22] which were in complete accordance with present data while moisture content was lower than present results. The difference in moisture content may be due to climatic condition. As water content of plants depends on the nature of the soil, the climatic condition and part of the plant used [33]. 
antidiabetic and anti-inflammatory activities. Certain tannins are also stated to hinder HIV replication [40]. Saponins are glycosides and present widely in plants. Saponins have antibiotic properties and protect against hypercholesterolemia and hyperglycemia. They possess anti-inflammatory, antioxidant, anticancer and central nervous system activities [40]. Steroids and triterpenoids show analgesic properties. Plant steroids are significant for their cardio tonic and central nervous system activities, analgesic, antiinflammatory, insecticidal and antimicrobial properties [41]. These plants are used traditionally for the treatment of cough, headache, inflammation, wound healing, expectorant, gastrointestinal disorders, carminative, asthma, antiseptic, antidiabetic, weight loss and so on due to the presence of secondary metabolites.

Table 2. Phytochemical screening of Aloe vera, Cannabis sativa and Mentha longifolia

\begin{tabular}{|c|c|c|c|c|}
\hline S. No. & Parameter & $\begin{array}{c}\text { A. vera } \\
\text { (leaves) }\end{array}$ & $\begin{array}{c}\text { C. sativa } \\
\text { (whole plant) }\end{array}$ & $\begin{array}{c}\text { M. longifolia } \\
\text { (whole plant) }\end{array}$ \\
\hline 1 & Alkaloids & + & + & + \\
\hline 2 & Flavonoids & + & + & + \\
\hline 3 & Tannins & + & + & + \\
\hline 4 & Saponins & + & + & + \\
\hline 5 & Triterpenoid & + & + & + \\
\hline 6 & Steroids & + & + & + \\
\hline 7 & Glycosides & - & + & \\
\hline
\end{tabular}

+: Present- : Absent

\section{Antioxidant activity}

Antioxidant activity of the acetonic extract of the selected plants was measured at various concentrations from 100 to $500 \mu \mathrm{g} / \mathrm{ml}$. The scavenging of free radicals $(\%)$ of plant extracted samples (Table 3) of A. vera, $C$. sativa and $M$. longifolia showed significant antioxidant property of $59 \%$ for $M$. longifolia, $61 \%$ for $C$. sativa and $64 \%$ for $A$. vera at $500 \mu \mathrm{g} / \mathrm{ml}$. Ascorbic acid was used in the research work as a standard antioxidant for all the selected plant extracts and displayed (Table 3) 38, 53, 68, 83 and $84(\%)$ antioxidant activity at $100-500 \mathrm{ug} / \mathrm{ml}$ concentration respectively. The data revealed that $A$. vera and $C$. sativa displayed strongest antioxidant activity in plants. Different methods are available for assessing the antioxidant activity of plants. The most simple, expedient and convenient assay for the determination of antioxidant property of medicinal plants is the radical scavenging method, with stable DPPH (1, 1 diphenyl-2picrylhydrazyl) radical by spectrophotometer. DPPH radical get an electron from antioxidant and decreases the absorbance [42]. For screening antioxidant activity, DPPH is extensively used because of its accommodation many samples and its sensitivity for detection active ingredients even in very low concentration [43]. Ascorbic acid has enhanced scavenging ability of DPPH than extracts. It was recognized that antioxidant property of the acetonic extracts (Table 3) of selected medicinal plants depends on concentration. Data revealed that radical scavenging activity (Figure 1) increased with increase in concentration.

Inhibition concentration ( $\left.\mathrm{IC}_{50}\right)$ parameter (Table 4) was employed in elucidating results from DPPH process. $\mathrm{IC}_{50}$ is actually the extract concentration at which $50 \%$ inhibition of DPPH achieved. It is negatively linked with the scavenging ability and expressed the antioxidant amount necessary for decreasing $50 \%$ radical. The lesser the $\mathrm{IC}_{50}$ value of the extract, the greater will be its antioxidant 
activity. The $\mathrm{IC}_{50}(\mu \mathrm{g} / \mathrm{ml})$ was found 428 for $M$. longifolia, 353 for $A$. vera and $C$. sativa.

$\mathrm{IC}_{50}$ was obtained from linear regression curve (Figure 1) of concentration against the percent scavenging activity. Literature exposed that the antioxidant property of plants is due to the presence of phenolic compounds such as terpenes, flavonoids, saponins and poly phenol which has free radical scavenging activity. The presence of tannins and flavonoids in majority of plants was responsible for the observed free radical scavenging effects [44].

Table 3. DPPH radical scavenging activity (\%) of acetonic extracts of Aloe vera, Cannabis sativa and Mentha longifolia

\begin{tabular}{|c|c|c|c|c|}
\hline Conc $(\boldsymbol{\mu g} / \mathbf{m l})$ & A. vera & C. sativa & M. longifolia & Vitamin C \\
\hline 100 & $24 \pm 0.70^{*}$ & $26 \pm 0.55$ & $16 \pm 1.12$ & $38 \pm 1.01$ \\
\hline 200 & $38 \pm 1.64$ & $37 \pm 1.00$ & $24 \pm 0.55$ & $53 \pm .1 .08$ \\
\hline 300 & $47 \pm 0.64$ & $46 \pm 0.90$ & $36 \pm 0.45$ & $68 \pm 1.18$ \\
\hline 400 & $53 \pm 1.52$ & $55 \pm 1.12$ & $44 \pm 0.79$ & $83 \pm 1.43$ \\
\hline 500 & $64 \pm 1.21$ & $61 \pm 0.85$ & $59 \pm 1.02$ & $84 \pm 1.62$ \\
\hline
\end{tabular}

$*$ Mean \pm S.D $(n=3)$

Table 4. DPPH radical scavenging activity of Aloe vera, Cannabis sativa and Mentha longifolia (IC 50 in $\mu \mathrm{g} / \mathrm{ml}$ )

\begin{tabular}{|c|c|c|}
\hline S. No & Acetonic extracts & IC 50 \\
\hline 1 & A. vera & $353 \mu \mathrm{g} / \mathrm{ml}$ \\
\hline 2 & C. sativa & $353 \mu \mathrm{g} / \mathrm{ml}$ \\
\hline 3 & M. longifolia & $428 \mu \mathrm{g} / \mathrm{ml}$ \\
\hline 4 & Vitamin C & $167 \mu \mathrm{g} / \mathrm{ml}$ \\
\hline
\end{tabular}

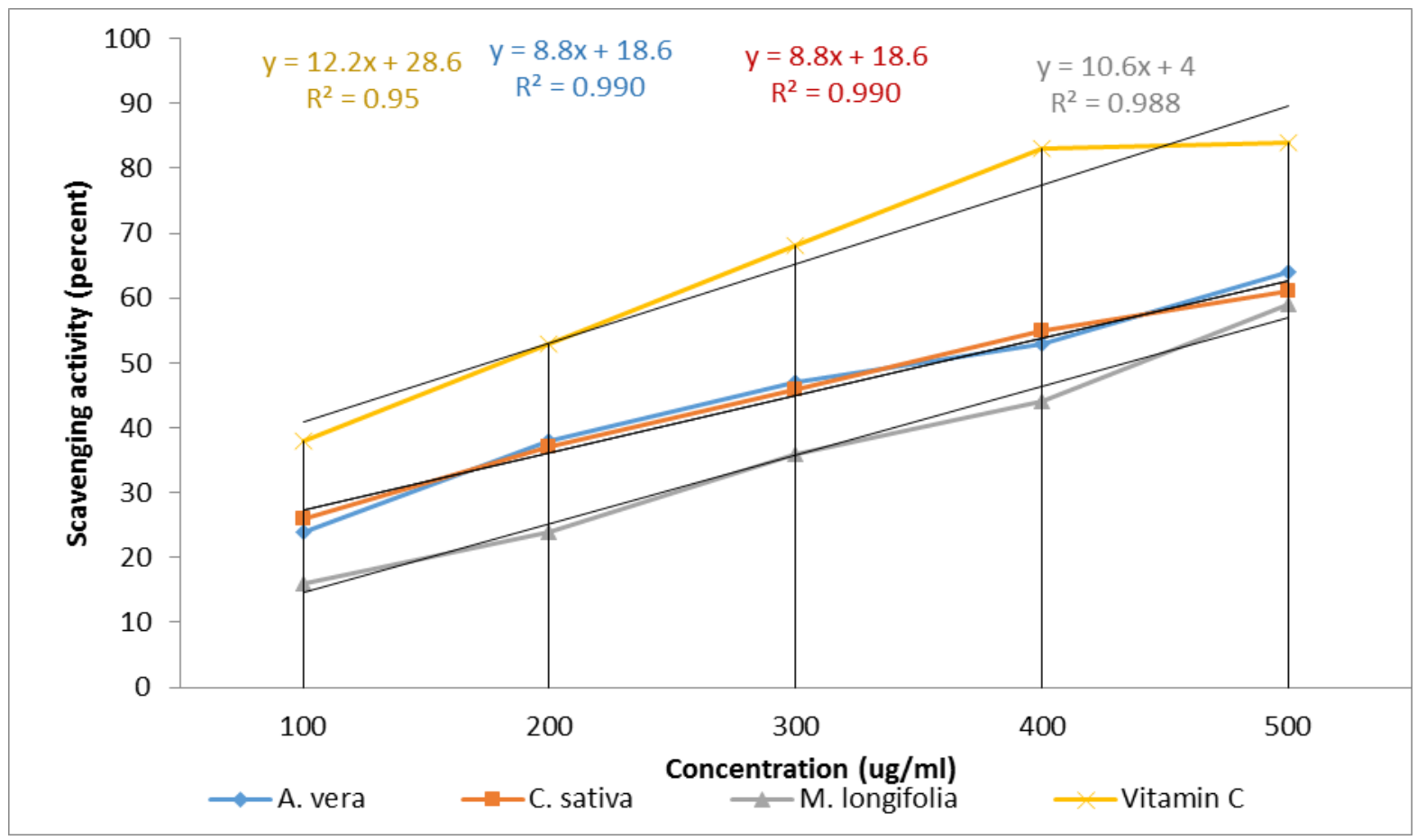

Figure 1. Antioxidant activities (DPPH) of A. vera, C. sativa and M. longifolia 


\section{Conclusion}

The present research work is an effort in confirming the nutritive value, phytochemical combination and antioxidants ability of selected plants. Proximate analysis revealed that these plants are good source of nutrients like proteins, fiber and fat. Most of the plants contained phytochemicals like alkaloids, tannins, flavonoids, glycoside etc which have good pharmacological effect. Among the selected medicinal plants, $C$. sativa has shown the presence of all tested phytochemicals. Both $C$. sativa and A. vera has shown significant antioxidant activity. Thus these plants could be utilized in food and as herbal products.

\section{Author's contributions}

Conceived and designed the experiments: $\mathrm{Z}$ Waris \& Y Iqbal, Performed the experiments: Z Waris, Analyzed the data: A Hussain, Shafqatullah \& AA Khan, Contributed reagents/materials/ analysis tools: MW Khan \& A Ali, Wrote the paper: A Ali.

\section{References}

1. Harborne JB (1984). Phytochemical Methods: A Guide to Modern Techniques of Plant Analysis, 2nd edn. Chapman and Hall, New York.

2. Titz A (2004). Medicinal Herbs and Plants Scope for Diversified and Sustainabl Extraction, Bangalore, India.

3. Davidson H (2000). Ecological ethnobotany: stumbling toward new practices and paradigms. MASA $J$ 16: 1-13.

4. Maciel MAM, Pinto AC, Veiga Jr VF, Grynberg NF and \& Echevarria A (2002). Medicinal plants: the need for multidisciplinary scientific studies. Quim Nova 25(3): 429-38.

5. Funari CS \& Ferro VO (2005). Ethical use of the Brazilian biodiversity: necessity and opportunity. Rev Bras Farmacogn 15(2): 178-82.

6. Hoareau L \& Da Silva EJ (1999). Medicinal plants: a re-emerging health aid. Electronic J of Biotechnol 2(2): 57-70.

7. Hussain S, Siddiqui SU, Khalid S, Jamal A, Qayyum A \& Ahmad Z (2007). Allelopathic potential of Senna (Cassia angustifolia
Vahl.) on germination and seedling characters of some major cereal crops and their associated grassy weeds. Pak J Bot 39(4): 1145-1153.

8. Iwu M, Duncan, DR \& Okunji CO (1999). New Antimicrobials of Plant Origin In: Janick, J. (ed.), Perspective on New Crops and New uses. ASHS Press. Alexandria, VA. pp 107-108.

9. Rabe \& Staden JV (1997). J Ethnopharmacol 56: 81.

10. Haq I (1983). Medicinal plants. Hamdard Foundation Press, Pakistan.

11. Shinwari, ZK \& Qaiser M (2011). Efforts on conservation and sustainable use of medicinal plants of Pakistan. Pak J Bot 43(SI): 5-10.

12. Sandhu DS \& Heinrich M (2005). The use of health foods, spices and other botanicals in the Sikh community in London. Phytotherapy Res 19: 633-42.

13. Zaheer S, Inam UK, Habib U, Safdar S, Zahid H, Shahida B, Alam Z \& Abdul M (2014). Mineral profile of different medicinal plants and their quantitative analyses collected. Pak J Weed Sci Res 145154.

14. Zaidi SH (2001). Existing indigenous medicinal plant resources of Pakistan and their prospects for utilization. Medicinal plants of Pakistan pp 53.

15. Hussain JAL, Khan N \& Rehman M (2009). Afr J Biotechnol 8: 2725-2729.

16. Shinwari ZK (2010). Medicinal plants research in Pakistan. J Med Pl Res 4(3): 161176.

17. Okigbo RN \& Mmeka EC (2006). An Appraisal of Phytomedicine in Africa. KMITL Sci Tech J 6(2): 83-94.

18. Miladi S \& Damak M (2008). J De La Societe Chimique De Tunisie 10: 101-109.

19. Duthie GG \& Duthie SJ (2000). Nutr. Res. Rev 13: 79-106.

20. Ogu EO \& Agu RC (1995). A comparison of some chemical property of garcina kola and hops for Assessment of garcinia brewing value. Bioreosource Technol 54: 1-4.

21. Khalil MY, Moustafa AA \& Naguib NY (2007). World J of Agric Sci 3: 451-457.

22. Pattanayak P, Behera P, Das D \& Panda SK (2010). Ocimum sanctum Linn. A reservoir 
plant for therapeutic applications: An overview. Phcog Rev 4: 95-105.

23. Schafer H \& Wink M (2009). Medicinally important secondary metabolites in recombinant microorganisms or plants: progress in alkaloid biosynthesis. Biotechnol $J$ 4(12): 1684-1703.

24. Mazid M, Khan TA, Mohammad F (2011). Role of secondary metabolites in defense mechanisms of plants. Biol and Medicine 3(2): 232-249.

25. Perumal SR, Ignacimuthu S, Patric \& Raja D (2008). Preliminary screening of ethnomedicinal plants from India. Eur Rev Med Pharmacol Sci 12: 1-7.

26. Lai PK \& Roy J (2004). Antimicrobial and chemopreventive properties of herbs and spices. Curr Med Chem 11(11): 1451-1460.

27. Tapsell LC, Hemphill I \& Cobiac L (2006). Health benefits of herbs and spices: The past, the present, the future. Med J Aust 185(4): 424.

28. Hashim S, Bakht T, Marwat KB \& Jan A (2014). Medicinal properties, phytochemistry and pharmacology of Tribulus terrestris L. (Zygophyllaceae). Pak J Bot 46: 399-404.

29. Ramawat KG \& Goyal S (2008). The Indian herbal drugs scenario in global perspectives. In: Ramawat KG, Merillon JM (eds) Bioactive molecules and medicinal plants. Springer, Berlin Heidelberg New York, pp 323.

30. Asomugha RN, Ezejiofor AN, Okafor PN \& Ljeh II. 2010. Acute and cytotoxicity studies of aqueous and ethanolic leaf extracts of Chromolaena odorata. Pak J Biolog Sci 18(2): 46-49.

31. Johnson JR, Burnell-Nugent M, BChir MB, Lossignol D, Ganae-Motan ED, Potts R \& Fallon M. 2010. Multicenter, double-blind, randomized, placebo-controlled, parallel group study of the efficacy, safety, and tolerability of thc:cbd extract and the extract in patients with intractable cancer-related pain. 2010. J Pain \& Symptom Management 39(2): 167-179.

32. Abdul Ghani, Ali Z, Islam T, Sanaullah S \& Saeed S (2014). Nutrient evaluation and elemental analysis of four medicinal plants of soon valley khushab, Pujab, Pakistan. Pak J Pharm Sci 27(3): 597-600.

33. Garodia P, Ichikawa H, Malani N, Sethi G \& Aggarwal BB (2007). From ancient medicine to modern medicine: ayurvedic concepts of health and their role in inflammation and cancer. J Soc Integr Oncol 5: 25-37.

34. Yue-Zhong S (1998). Recent natural products based drug development: a pharmaceutical industry perspective. $J$ of natural products. 61: 1053-1071.

35. Chin YW, Balunas MJ, Chai HB \& Kinghorn AD (2006). AAPS J 8:E239.

36. Butler MS (2004). The role of natural product chemistry in drug discovery. $J$ Natural Products 67(12): 2141-2153.

37. Lombardino JG \& Lowe JA (2004). The role of the medicinal chemist in drug discovery then and now. Nature Reviews Drug Discovery. 3(10): 853-862.

38. Sneader W (2005). Drug Discovery: A History, Wiley, Chichester, UK.

39. Rain Tree Nutrition (2011). Tropical plant database: Database for Quinine (Cinchona officinalis). [http://www.raintree.com/quinine.htm].

40. Covello PS (2008). Making artemisinin. Phytochem 69: 2881-2885.

41. Raskin I (2010). Role of salicylic acid in plants. Annual Rev of Plant Physiol.

42. Arcamone F, Cassinelli G \& Casazza AM (1980). New antitumor drugs from plants. $J$ of Ethnopharmacology 2: 149-160.

43. Elhardallou SB (2011). Cytotoxicity and biological activity of selected Sudanese medicinal plants. Res $J$ of Medicinal Plant 5: 201-229.

44. Hollman A (1985). Plants and cardiac glycosides. British heart J 54: 258-261. 